\title{
Identification of Distinct Potyviruses in Mixedly-Infected Sweetpotato by the Polymerase Chain Reaction with Degenerate Primers
}

\author{
D. Colinet, J. Kummert, P. Lepoivre, and J. Semal
}

Faculté des Sciences Agronomiques de l'Etat, Laboratoire de Pathologie Végétale, 5030 Gembloux, Belgium. Financially supported by EEC (Project STD3 TS3-CT91-0013).

We thank Dr. Kettmann for helpful discussions, Pr. Burny in whose laboratory part of this work was carried out, and Pr. Brunt

(AFRC Institute of Horticultural Research, Littlehampton, England) for supplying the SPLV isolate. Accepted for publication 24 September 1993.

\section{ABSTRACT}

Colinet, D., Kummert, J., Lepoivre, P., and Semal, J. 1994. Identification of distinct potyviruses in mixedly-infected sweetpotato by the polymerase chain reaction with degenerate primers. 84:65-69.

A combined assay of reverse transcription and the polymerase chain reaction utilizing degenerate primers derived from conserved regions in the genome of potyviruses was designed to amplify the variable 5 '-terminal region of the coat protein cistron. Amplification on total RNA extracted from two sweetpotato clones originating from China (Guangdong Province) yielded a $1.35-\mathrm{kb}$ fragment amplified from a sweetpotato feathery mottle virus (SPFMV) isolate from China (SPFMV-CH) associated with one or two other fragments ( 1.30 and $1.45 \mathrm{~kb}$ ), suggesting the presence of two other potyviruses in these sweetpotato clones. The 1.30- and 1.45$\mathrm{kb}$ amplified fragments were cloned into the Bluescript plasmid and partially sequenced. Comparison of the deduced partial amino acid sequences derived from the amplified fragments with those of the $C$ terminal region of the nuclear inclusion $b$ protein and the $\mathrm{N}$-terminal region of the coat protein of SPFMV-CH and of several other potyviruses indicated mixed infections by distinct potyviruses in the sweetpotato clones we investigated. Dot blot assays and preliminary sequence analysis indicate that the virus corresponding to the $1.30-\mathrm{kb}$ fragment is closely related to sweetpotato latent virus.
The potyvirus group includes viruses responsible for severe economic damage to various crops. Potyvirus particles are flexuous and rod shaped, $680-900 \mathrm{~nm}$ long, and $11-15 \mathrm{~nm}$ wide and are made up of about 2,000 units of a single structural protein surrounding one molecule of single-stranded positive-sense RNA of approximately 10,000 nucleotides (15). Sweetpotato may be affected by five major potyviruses (12), among which sweetpotato feathery mottle virus (SPFMV) is the most thoroughly characterized $(1,12)$ and is frequently identified worldwide as a component of viral complexes $(12,22)$. The ubiquitous nature of SPFMV interferes with isolation and identification of other sweetpotato viruses (12).

The polymerase chain reaction (PCR) enabled the detection of plant viruses belonging to geminiviruses $(18,19)$, luteoviruses (17), and potyviruses $(5,11,13)$. In previous work, we developed a rapid method for the amplification of large fragments of the genome of a SPFMV isolate from China (SPFMV-CH), using PCR with degenerate primers (5).

Sequence comparisons and biochemical analysis showed that the N-termini of the coat protein of distinct potyviruses may vary considerably in length and sequence, whereas the C-terminal twothirds of the protein is highly conserved (21). We report here on the use of degenerate primers designed to amplify the variable 5 -terminal region of the coat protein cistron (5) to detect distinct sweetpotato potyviruses in mixed infections.

\section{MATERIAL AND METHODS}

Virus isolates and plant materials. Sweetpotato clones (Ipomoea batatas L.) 1 and 530 originated from China, Guangdong Province (F. Zoxia, Upland Crops Research Institute, Guangzhou) and were maintained in Gembloux, Belgium, under greenhouse conditions. SPFMV-CH was propagated by mechanical transmission in $I$. purpurea. Sweetpotato latent virus (SPLV) was received from A. Brunt and propagated by mechanical transmission in Nicotiana benthamiana and N. clevelandii. Potato virus Y (PVY),

1994 The American Phytopathological Society used as the potyvirus reference strain, was maintained by mechanical transmission in $N$. tabacum cv. Samsun. Aphid transmission assays were carried out with Myzus persicae (acquisition time: $5-10 \mathrm{~s}$; transmission time: $3 \mathrm{~h}$ ).

RNA extraction and cDNA synthesis. Total RNA was extracted from symptomatic leaves by the method of Chirgwin et al (4). Single-stranded cDNA was synthesized from $5 \mu \mathrm{g}$ of total RNA with the Amersham cDNA synthesis kit (Amersham International, Amersham, England) and was diluted 10 -fold with sterile water. Five microliters of these preparations was used for the PCR amplifications.

PCR experiments. The degenerate primers were derived from conserved regions of the genome of potyviruses encoded by codons of low degeneracy (5). The nucleotide sequence between the two primers, Pot 1 (a 25-mer oligonucleotide with a 18-fold degeneracy) and Pot 2 (a 26-mer oligonucleotide with a 24-fold degeneracy) spans part of the nuclear inclusion $b$ protein and the coat protein cistrons (Fig. 1). To facilitate the cloning of the PCR products, sequences containing EcoRI or BamHI restriction sites were added at the $5^{\prime}$ end of the primers. PCR experiments were performed as described previously (5). Amplification of the cDNAs was performed in a volume of $100 \mu \mathrm{l}$ of PCR buffer (10 mM Tris- $\mathrm{mCl}$, pH 9.0, $2.5 \mathrm{mM} \mathrm{MgCl}_{2}, 50 \mathrm{mM} \mathrm{KCl}, 0.1 \%$ Triton X-100) containing $200 \mu \mathrm{M}$ each of dATP, dCTP, dGTP, and dTTP, $0.1 \mathrm{nmol}$ each of upstream and downstream primers, and 5 units of Taq DNA polymerase (Promega, Madison, WI). The following thermal cycling scheme was used for 37 reaction cycles (Biometra cycler, Göttingen, Germany): template denaturation at $94 \mathrm{C}$ for $30 \mathrm{~s}$, primer annealing at 40 (cycles 1-5) or $50 \mathrm{C}$ (cycles 6-37) for $1 \mathrm{~min}$, and DNA synthesis at $72 \mathrm{C}$ for $2 \mathrm{~min}$. A final 15 -min elongation step at $72 \mathrm{C}$ was performed at the end of the 37 cycles. Amplification products were analyzed by electrophoresis of $10 \mu \mathrm{L}$ from each reaction mixture in a $1 \%$ agarose gel, in Tris-acetate, EDTA buffer (20). Bands were visualized by ethidium bromide staining.

Cloning of the amplified fragments. Amplification products were extracted twice with phenol-chloroform and precipitated by addition of 0.1 volume of $3 \mathrm{M}$ sodium acetate, $\mathrm{pH} 5.8$, and 2 volumes of ethanol. The pellets were resuspended in $50 \mu \mathrm{l}$ of 
water and digested with $\mathrm{BamHI}$ and EcoRI. After electrophoresis in $1 \%$ agarose gel, bands of the expected lengths were excised and eluted with the QIAEX gel extraction kit from QIAGEN (Qiagen Inc., Chatsworth, CA). The DNA fragments were directionally cloned into the Bluescript plasmid digested with Bam HI and EcoRI. Recombinant plasmids were monitored for appropriately sized inserts by cleavage with $P v u I I$.

DNA sequencing and analysis. The nucleotide sequence was obtained either by subcloning the amplified fragments by cleavage with restriction enzymes or by specific primers derived from the sequences. Double-stranded DNA sequencing by the dideoxy chain termination method was performed with T7 DNA polymerase (Pharmacia, Inc., Biotechnology Group, Piscataway, NJ) according to manufacturer's instructions.

Southern blotting. Amplified fragments were analyzed in $1 \%$ agarose gels and subsequently transferred to nylon membranes (Hybond-N, Amersham Corporation). Digoxigenin labeling and hybridization were performed with the DIG DNA labeling and DIG luminescent detection kits from Boehringer (Mannheim, Germany) according to manufacturer's instructions.

Sample preparations for dot blotting. For dot blot assays, infected or healthy leaves were ground in water treated with diethyl pyrocarbonate $(1: 3, \mathrm{w} / \mathrm{v})$, and the extracts were centrifuged for $5 \mathrm{~min}$ at $13,000 \mathrm{rpm}$. Serial dilutions $(1 \mu \mathrm{l})$ were blotted onto nylon membranes (Hybond-N), which were subsequently baked for $15 \mathrm{~min}$ at $80 \mathrm{C}$ and fixed under ultraviolet light for $5 \mathrm{~min}$.

\section{RESULTS}

Amplification and cloning of the PCR products. The amplifications were carried out on total RNA isolated from sweetpotato clones 1 and 530, using degenerate primers designed to amplify the variable 5'-terminal region of the coat protein cistron together with the 3'-terminal region of the nuclear inclusion $b$ protein cistron of potyviruses (Fig. 1) (5). Positive controls consisted of total RNA isolated from $N$. tabacum cv. Samsun infected with $\mathrm{PVY}$ and from I. purpurea infected with SPFMV-CH. The length of the amplified fragments obtained with PVY $(1.2 \mathrm{~kb})$ and SPFMV-CH $(1.35 \mathrm{~kb})$ corresponded to those expected from the position of the primers on the known sequences of these viruses

P1 HC-Pro P3
\begin{tabular}{|l|l|l|l||l|l|l|l|}
\hline & & & & Cl & 6K Nla & Nlb & CP \\
\hline
\end{tabular}

$$
\begin{aligned}
& \text { W C I } \begin{array}{lll}
\frac{\text { Pot } 1}{E} & \text { N } \\
& & \text { D }
\end{array} \\
& \text { 3' ACC ACG TAT CTT TTA cCtaggtcag 5' } \\
& \text { A G G } \\
& \text { A C BamHI } \\
& \text { Pot } 2 \\
& C D A D G S \\
& \text { 5' gacgaattc TGT GAT GCT GAT GGT TC }{ }^{31} \\
& \text { ECORI } \\
& \text { C }
\end{aligned}
$$

Fig. 1. Genetic map of the potyvirus genome, showing the relative positions f the two degenerate primers based on selected conserved regions (Pot 1 and Pot 2). Lowercase letters represent nucleotides not derived from the viral sequences. P1: first protein; HC-Pro: helper component-protease P3: third protein; CI: cytoplasmic inclusion protein; $6 \mathrm{~K}$ : $6 \mathrm{~K}$ peptide; NIa: nuclear inclusion a protein; NIb: nuclear inclusion b protein (RNA polymerase); CP: coat protein.
(Fig. 2) $(5,16)$. Amplification of the variable 5'-terminal region of the coat protein cistron on total RNA extracted from sweetpotato clones 1 and 530 yielded the SPFMV-specific fragment $(1.35 \mathrm{~kb})$ associated with one or two other fragments (1.30 and $1.45 \mathrm{~kb}$ ) (Fig. 2). The 1.45-kb fragment was amplified from RNA extracted from both clones 1 and 530 , whereas the $1.30 \mathrm{~kb}$ was amplified only from RNA extracted from clone 1 . The specificity of PCR was validated by amplification of the 1.30 - and 1.45 kb PCR products on RNA extracted from either $I$. setosa grafted with sweetpotato clone 530 or from $I$. setosa infected by aphid transmission from this same clone (Fig. 3). No fragments were amplified on RNA extracted from healthy $I$. setosa. The 1.30and $1.45-\mathrm{kb}$ PCR products were cloned into the Bluescript plasmid.

Comparison of the deduced amino acid sequences of the PCR products with other potyviruses. Because of the low fidelity of the Taq DNA polymerase, which may lead to misincorporations, the partial nucleotide sequences of the $1.30-$ and $1.45-\mathrm{kb}$ amplified fragments were determined from three independent clones obtained from one amplification.

The partial deduced amino acid sequences of the 1.30- and $1.45-\mathrm{kb}$ amplified fragments were aligned with those of part of the $\mathrm{C}$-terminal region of the nuclear inclusion b protein (Fig. 4) and the $\mathrm{N}$-terminal region of the coat protein (Fig. 5) of SPFMV-CH (5), plum pox virus (10), potato virus Y (PVY; 16), tobacco etch virus (TEV; 2 ) and tobacco vein mottling virus (TVMV; 6). Alignment in Figure 4 revealed the presence in the deduced amino acid sequences of the 1.45 - and the $1.30-\mathrm{kb}$ fragments, of the consensus motif GNNSGQPSTVVDNTLMV, involved in the putative RNA polymerase function of potyviruses $(2,7,9,14)$. Alignment in Figure 5 revealed the presence of the putative glutamine (Q)/ serine (S) and glutamine (Q)/ aspartic acid (A) cleavage sites for the coat protein (15) in the amino acid sequences of the 1.45 - and $1.30-\mathrm{kb}$ fragments, respectively. The second significant domain in the amino acid sequences of the 1.45 - and $1.30-\mathrm{kb}$ fragments was the DAG box involved in aphid transmission of potyviruses (3).

Hybridization experiments between SPLV and the amplified fragments. Amplified fragments (1.45 and $1.30 \mathrm{~kb}$ and SPFMV$\mathrm{CH} 1.35 \mathrm{~kb}$ ) were labeled with digoxigenin (Boehringer). Series of hybridizations were performed after transfer of amplified fragments from agarose gels to nylon membranes. No crosshybridization was detected between the three fragments, each probe hybridizing exclusively to the homologous DNA (Fig. 6).

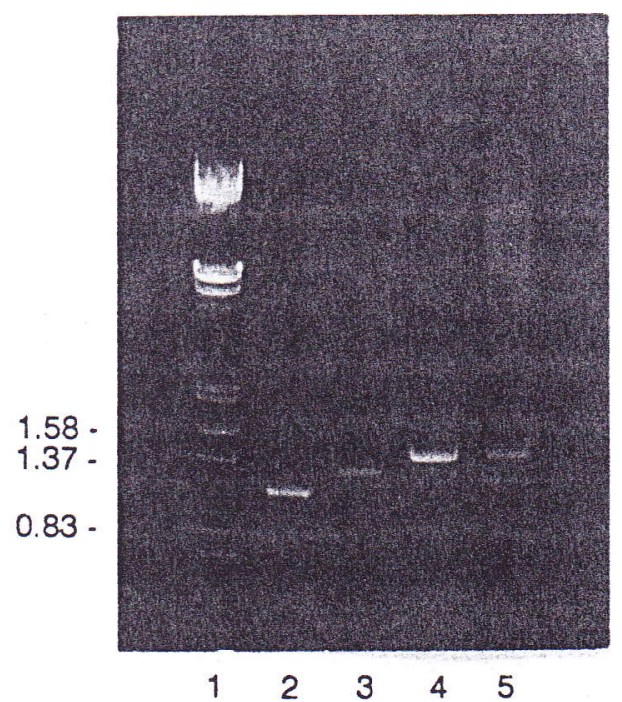

Fig. 2. Analysis of polymerase chain reaction products amplified with degenerate primers (Pot 1 and Pot 2). Lane 1, DNA size markers, fragment sizes (in kilobases) indicated on the left; lane 2, product amplified from potato virus Y; lane 3, product amplified from sweetpotato feathery mottle virus from China; lanes 4 and 5, product amplified from sweetpotato clones 530 and 1 , respectively. 
Dot blot experiments with crude sap from $N$. benthamiana infected with SPLV and the three amplified fragments as probes revealed specific hybridization between SPLV and the 1.30-kb fragment (Fig. 7). No hybridization was detected between SPLV and the two other fragments. No nonspecific hybridization with sap from healthy plants was detected.

\section{DISCUSSION}

The PCR procedure utilizing degenerate primers designed to amplify the variable 5'-terminal region of the potyvirus coat protein cistron is a rapid and sensitive technique for detecting and characterizing members of the potyvirus group $(5,11,13)$. A combined assay of reverse transcription followed by PCR on total RNA extracted from two sweetpotato clones from China yielded a $1.35-\mathrm{kb}$ fragment amplified from SPFMV associated with one or two other fragments (1.30 and $1.45 \mathrm{~kb}$ ), suggesting the presence of two other potyviruses.

Comparison of the partial deduced amino acid sequences derived from the 1.30 - and $1.45-\mathrm{kb}$ amplified fragments with those of SPFMV-CH (5) and several other potyviruses $(2,6,10,16)$ revealed consensus motifs $(1,3,7,9,14,15)$ and more than $78 \%$ homology in the C-terminal region of the nuclear inclusion b protein. Homology was lower (less than $60 \%$ ) in the N-terminal region of the coat protein, which is known to differ greatly in length for distinct potyviruses (21). The putative $\mathrm{N}$-terminal region of the coat protein derived from the $1.45-\mathrm{kb}$ fragment was significantly larger than those of other described potyviruses. Such a difference in length combined with a low level of homology in the coat protein amino acid sequence is characteristic for distinct potyviruses (21). These results, together with those of our crosshybridization studies, lead us to conclude that the 1.30 - and 1.45 $\mathrm{kb}$ fragments were amplified from distinct potyviruses infecting the two sweetpotato clones.

To further identify these potyviruses, the 1.30 - and $1.45-\mathrm{kb}$ PCR products were hybridized with crude sap extracted from $N$. benthamiana infected with SPLV under high-stringency hybridization conditions. Specific hybridization of the 1.30-kb fragment identified the corresponding virus as closely related to SPLV. This close relationship was corroborated by the amplification of a 1.30-kb fragment on total RNA isolated from $N$. benthamiana infected with SPLV (D. Colinet, unpublished data) and by the

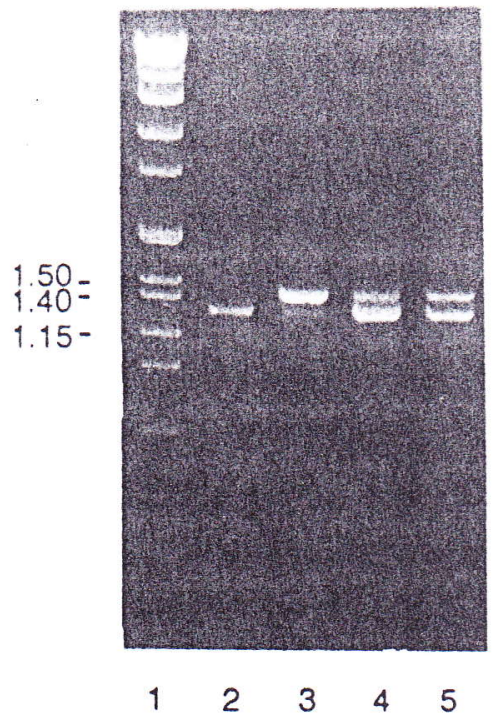

Fig. 3. Analysis of polymerase chain reaction products amplified with degenerate primers (Pot 1 and Pot 2). Lane 1, DNA size markers, fragment sizes (in kilobases) indicated on the left; lane 2 , product amplified from sweetpotato feathery mottle virus from China; lane 3 , product amplified from sweetpotato clone 530; lane 4, product amplified from Ipomoea setosa grafted with clone 530; lane 5, product amplified from $I$. setosa after aphid transmission from clone 530 . preliminary sequence analysis of this SPLV-specific $1.30-\mathrm{kb}$ fragment that indicated a high level of homology (more than $90 \%$ ) in the $\mathrm{N}$-terminal region of the coat protein cistron with the sequence of the $1.30-\mathrm{kb}$ fragment amplified from sweetpotato clone 1 (D. Colinet, unpublished data). SPLV has no known insect vector but was recently found to be serologically related to typical aphid-transmitted members of the potyvirus group (8). Our sequence analysis of the capsid protein gene of the SPLVlike virus from China and, more particularly, the presence of the DAG box involved in aphid transmission (3) confirmed this relationship.

The deduced amino acid sequence of the N-terminal region of the coat protein of the $1.45-\mathrm{kb}$ fragment also contained the DAG box. Moreover, this fragment was amplified after aphid transmission in the presence of SPFMV from sweetpotato clone 530 to the test plant, $I$. setosa, indicating this fragment was amplified from a potyvirus related to typical aphid-transmitted members of the virus group. Apart from SPFMV, only sweetpotato vein mosaic virus (SPVMV) has been described as an aphid-transmitted potyvirus infecting sweetpotato (12). SPVMV has been reported only in Argentina and has not been adequately characterized (12). The two other known potyviruses infecting

\begin{tabular}{|c|c|c|c|c|c|c|c|c|}
\hline $1-2(1.45)$ & $Q F$ & $D \mid S S L$ & $S P$ & $\mathrm{p}$ & L I N & $S V L$ & \begin{tabular}{ll|l}
$N$ & I & $R$
\end{tabular} & Q L H F \\
\hline $2(1.30)$ & Q F & $D \mid S S L$ & $S P$ & $Y$ & L I N & A $V$ L L & $Q \quad L$ & R L H F \\
\hline$=\mathrm{MV}-\mathrm{CH}$ & $\begin{array}{llll}Q & F & 1\end{array}$ & $H \mid S S S$ & 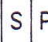 & $Y$ & L I N & $S V L$ & \begin{tabular}{ll|l}
$N$ & I & $R$
\end{tabular} & $R E F$ \\
\hline & Q $F$ & $D S S L$ & $S \mid P$ & $Y$ & L I N & A $V$ L L & N I & R L A A F \\
\hline & $Q \quad F$ & $D \mid S S L$ & $T P$ & $Y$ & L I N & A $V$ L & \begin{tabular}{ll|l} 
& $I$ & $R$
\end{tabular} & $R S T Y$ \\
\hline & Q $F$ & $D S S L$ & $T F$ & $F$ & L I N & A $V$ L L & 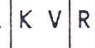 & $R \quad L A F$ \\
\hline IMV & Q F & $D \leq S \quad S \quad L$ & $S L$ & $P Y$ & $L$ I N & $A \cup L$ & $R L R$ & $R \perp S S$ \\
\hline$-2(1.45)$ & $M E$ & K $W$ W $E$ I I & G & $Q T$ & M L K & $N L Y$ & 15 & Y T \\
\hline$-2(1.30)$ & $M E$ & $E$ E $W: D A$ & $G$ & $E Q$ & $M L R$ & $N L Y$ & $T E I$ & $I V Y T$ \\
\hline FMV - CH & $M E$ & $D W D V$ & $G D$ & $\mathrm{DH}$ & $M L R$ & $N L Y$ & $T E I$ & $I \vee Y T$ \\
\hline & $M E$ & 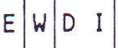 & G $\mathrm{E}$ & $E Q$ & $M L S$ & $N L Y$ & $T E I$ & $I \vee Y T$ \\
\hline & $M E$ & $D W D V$ & G & L Q & $M L R$ & $N L Y$ & $T E I$ & $I V Y T$ \\
\hline & $M E$ & $E$ E $W: D C I$ & $G$ & $E Q$ & $M L R$ & $N L Y$ & $T E I$ & $I \vee Y T$ \\
\hline & $M E$ & $E[W] D V$ & L & & $M L Q$ & $N<Y$ & $T E I$ & \\
\hline
\end{tabular}

\begin{tabular}{|c|c|c|}
\hline$-2(1.45)$ & $\begin{array}{llll}P & I & L\end{array}$ & $\mid T P D G G$ \\
\hline$-2(1.30)$ & \begin{tabular}{ll|l}
$P$ & $I$ & $L$
\end{tabular} & $\mid \begin{array}{lllllll} & P & D & G & T & I & I\end{array}$ \\
\hline PFMV-CH & $\begin{array}{llll}P & I & L\end{array}$ & $-T P D G I I V$ \\
\hline PV & \begin{tabular}{l|l}
$P$ & $I$
\end{tabular} & $S$ T P D D G T I \\
\hline VY & \begin{tabular}{ll|l}
$P$ & $\mathrm{~S}$
\end{tabular} & 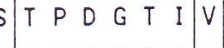 \\
\hline EV & \begin{tabular}{ll|l}
$P$ & $I$ & $L$
\end{tabular} & 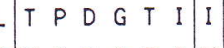 \\
\hline VMV & $\mathrm{PIS}$ & 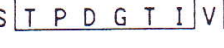 \\
\hline$-2-1.45)$ & $S T V$ & $\checkmark D N N T L M V$ \\
\hline $1-2(1.30)$ & $S T V$ & $\forall V D N L M V$ \\
\hline SPFMV-CH & $S T V$ & $\checkmark V D N T L M V$ \\
\hline PPV & $S T V$ & $\checkmark V D N T L M V$ \\
\hline VY & $S T V$ & $\checkmark V D N S L M V$ \\
\hline EV & $S T V$ & $\checkmark V D N T L M V$ \\
\hline MV & $S T V$ & $V \vee D N T L M$ \\
\hline
\end{tabular}

Fig. 4. Alignment of the deduced amino acid sequences of the 1.30-kb $(1-2(1.30))$ and $1.45-\mathrm{kb}(1-2(1.45))$ amplified fragments with those of part of the C-terminal region of the nuclear inclusion b protein of sweetpotato feathery mottle virus from China (SPFMV-CH), plum pox virus (PPV; from aa 2544 to aa 2615), potato virus Y (PVY; from aa 2528 to aa 2600 ), tobacco etch virus (TEV; from aa 2530 to aa 2602), and tobacco vein mottling virus (TVMV; from aa 2475 to aa 2547). Amino acids identical in all sequences are boxed. 
sweetpotato, sweetpotato mild mottle virus and sweetpotato yellow dwarf virus, are whitefly-transmitted and are not related to typical aphid-transmitted members of the group $(8,12)$. Hybridization studies with our $1.45-\mathrm{kb}$ fragment would determine whether the unidentified potyvirus is related to SPVMV or is a new sweetpotato virus belonging to the potyvirus group.

In summary, amplification of fragments of different lengths, including the variable $\mathrm{N}$-terminal region of the coat protein, pro- vides a convenient method for detecting mixed infections by distinct potyviruses and new members of the potyvirus group, without the fastidious preliminary work of separation and purification of the components of viral complexes. The data obtained from subsequent molecular analysis of the amplified genomic regions can be used for classification and taxonomic studies, whereas the amplified fragments can be used to develop nucleic acid hybridization tests.

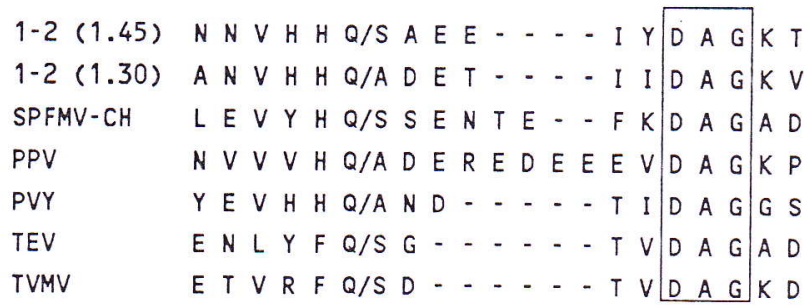

1-2(1.45) GNTGRGRGRGTVPPPPPPPGA $1-2(1.30) \ldots \ldots \ldots$ SPFMV-CH $\ldots \ldots \ldots$ PPV PVY TEV TVMV

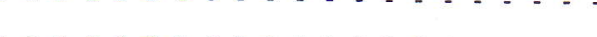

- - . - - - - - - -

$1-2(1.45)$ PRTGDLPPAVQTGPLPPGAAS $1-2(1.30) \ldots \ldots \ldots$ SPFMV-CH $\ldots \ldots \ldots$ PPV $\quad \cdots .-S V V T$ A P A A T SPI LO PVY $\ldots \ldots \ldots \ldots$ TEV $\ldots \ldots \ldots \ldots$ TVMV

1-2 (1.45) KP P I I EE I LQPESPRTKALRE $1-2(1.30) \ldots \ldots \ldots$ SPFMV-CH PPAPKSKINPPPPTI TEVVDP PPV PPPVIQPAPRTTASMLNPIFT PVY $\quad \ldots \ldots \ldots \ldots$ TEV $\quad \ldots \ldots \ldots \ldots$ TVMV $\quad \ldots \ldots \ldots \ldots$

$1-2(1.45)$ ARGKAPATIPDSRGVDTSQ I P $1-2(1.30)$ E AKKNQNTEGTQPRTNTPTQP SPFMV-CH EDPNQAALKAARAKQPATIPE PPV PATTQPATKPVSQVPGPQLQT PVY $\ldots \ldots \ldots$ TEV $\quad \ldots \ldots \ldots$ TVMV

1-2 (1.45) SFTPGRDQTMTPTPQRTSTEV $1-2(1.30)$ SPSDKGKEVISSKRE I I RTPE SPFMV-CH SYGRDTSKEKESIVGTSSKGV PPV FGTYGNEDASPSNSNALVNTN PVY - IKKDAKDEQESIQPMPNKE TEV - - A A KKKKDQKDDKVAEQAS TVMV

\begin{tabular}{|c|c|c|c|c|c|c|c|c|c|c|}
\hline $1-2(1.45)$ & $\mathrm{R}$ & $\begin{array}{l}D \\
D\end{array}$ & $D$ & $\checkmark N A$ & \begin{tabular}{|l|l}
$G$ & $T$ \\
\end{tabular} & $v$ & $G T$ & F I V & $P R$ & $R \quad P \quad Q$ \\
\hline $1-2(1.30)$ & $\mathrm{HS}$ & & 0 & I N N T C & $\begin{array}{ll}G & T\end{array}$ & 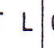 & $G T$ & $F Q V$ & $P R$ & R R \\
\hline SPFMV-CH & $\mathrm{R}$ & & D & $V N \vee$ & & v & $G \quad T$ & $F \vee V$ & $P R$ & \\
\hline PV & $R$ & & $D$ & $\checkmark D A$ & & $v$ & $G T$ & $F T V$ & $P R$ & \\
\hline IY & $\mathrm{K}$ & $D K$ & $D$ & 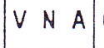 & \begin{tabular}{l|l}
$G$ & $T$
\end{tabular} & $s \mid c$ & $G T$ & H T V & $P R$ & I K \\
\hline & $k$ & $\begin{array}{ll}D & R\end{array}$ & $D$ & $\checkmark M A$ & & $s$ & $G T$ & F S V & $P R$ & \\
\hline & & & & & & & & & & \\
\hline
\end{tabular}

$1-2(1.45)$ HSKKTAPM ANGRIVVNLDHLT $1-2$ (1.30) P T K I R L P L VKCGAALN L D H L L SPFMV-CH ANKKR Q P M $V$ N N GR A I I I N F Q H L L PPV TSKLSLP KVKGKA I M N L N H L A PVY TSKMRMPTSKGATVLNLEHLL TEV ATKLQYPRMRGEYVVNLNHLL TVMV AMNMKLPKVGGSSVVNLDHLL

\begin{tabular}{|c|c|c|c|c|c|c|c|}
\hline $1-2(1.45)$ & I & $Y D$ & 0 & $E \mid Q$ & $T S L S$ & $N \mid T R A T Q E Q$ & $F$ \\
\hline $2(1.30)$ & $\mathrm{v}$ & $Y \mid K$ & $P$ & $S Q$ & $\begin{array}{llll}L & D & I & T\end{array}$ & $\begin{array}{llllllll}N & A & K & A & T & R & S & Q\end{array}$ & F N \\
\hline $\mathrm{FMV}-\mathrm{CH}$ & $T$ & $Y E$ & $\mathrm{P}$ & $E Q$ & $Y E \vee A$ & \begin{tabular}{l|llllll}
$N$ & $T$ & $R$ & $S$ & $T$ & $Q$ & $E$
\end{tabular} & $F Q$ \\
\hline & $H$ & Y $S$ & $\mathrm{p}$ & $A Q$ & $V D L S$ & 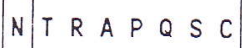 & $F$ \\
\hline & E Y & Y A & $P$ & $Q Q$ & I $\quad D$ I $S$ & \begin{tabular}{l|lllllll}
$N$ & $T$ & $R$ & $A$ & $T$ & $Q$ & $S$ & $Q$
\end{tabular} & F D T \\
\hline & $G Y$ & & $\mathrm{P}$ & $Q Q$ & $I D L S$ & 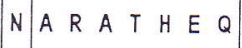 & $\mathrm{F}$ \\
\hline & & & & & & & \\
\hline
\end{tabular}

$1-2$ (1.45) WYEGVREDYGVNDEQMG I L N $1-2(1.30)$ W Y E G V K K N A Y E V D D Q Q M S I L M N SPFMV-CH W Y E G V K K G D Y G V D D T G M G I L L N PPV WYYEGVVKR D Y DV T D DEEMSS I I L N PVY WY YEAVVRMAYDI GETEMPPTVMN TEV WHQAVMTAYGVNEEQMKILLN TVMV WH T N V MAELELNEE QLM K I V L N

\begin{tabular}{|c|c|c|}
\hline $9-2(9.45)$ & $G$ & $L M V$ \\
\hline $1-2(1.30)$ & $G$ & $\vee \vee v$ \\
\hline SPFMV-CH & G & $L M$ \\
\hline PPV & G & L M V \\
\hline VY & $G$ & $L M V$ \\
\hline TEV & G & $F M$ \\
\hline & & \\
\hline
\end{tabular}

Fig. 5. Alignment of the deduced amino acid sequences of the $1.30-\mathrm{kb}(1-2(1.30))$ and $1.45-\mathrm{kb}(1-2(1.45))$ amplified fragments with those of the $\mathrm{N}$-terminal region of the coat protein of sweetpotato feathery mottle virus from China (SPFMV-CH), plum pox virus (PPV), potato virus Y (PVY), tobacco etch virus (TEV), and tobacco vein mottling virus (TVMV). Amino acids identical in all sequences are boxed. "” indicates the putative cleavage site between the nuclear inclusion protein and the coat protein of potyviruses. 
A

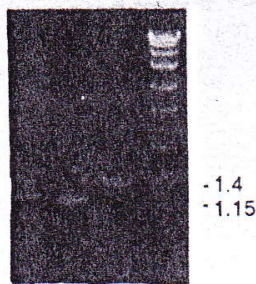

$\begin{array}{llll}1 & 2 & 3 & 4\end{array}$

B

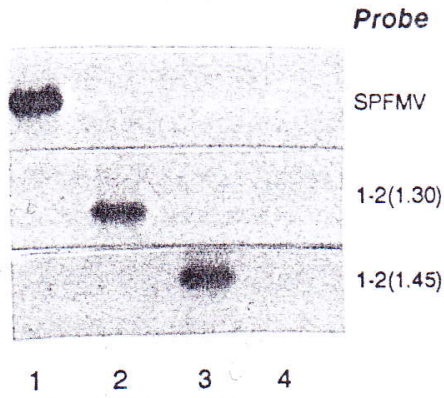

Fig. 6. Cross-hybridization studies between the sweetpotato feathery mottle virus from China (SPFMV-CH) $1.35-\mathrm{kb}$ (lanes 1) amplified fragment and the 1.30- (lanes 2) and 1.45-kb (lanes 3) amplified fragments. A, Ethidium bromide-stained $1 \%$ agarose gel; lanes 4 , DNA size markers, fragment sizes (in kilobases) indicated on the right. B, Southern blot analyses with the digoxigenin-labeled SPFMV-CH $1.35-\mathrm{kb}$ and the 1.30 and $1.45-\mathrm{kb}$ amplified fragments as probes.

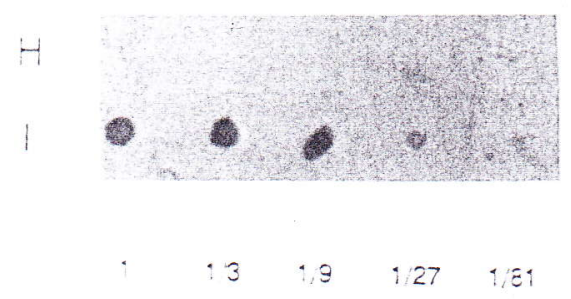

Fig. 7. Dot blot hybridization test between the digoxigenin-labeled 1.30$\mathrm{kb}$ amplified fragment and sweetpotato latent virus (SPLV). H: Serial threefold dilutions of crude extract of healthy Nicotiana benthamiana; I: serial threefold dilutions of crude extract of SPLV-infected $N$. benthamiana.

\section{LITERATURE CITED}

1. Abad, J. A., Conkling, M. A., and Moyer, J. W. 1992. Comparison of the capsid protein cistron from serologically distinct strains of sweetpotato feathery mottle virus (SPFMV). Arch. Virol. 126:147157.

2. Allison, R., Johnston, R. E., and Dougherty, W. G. 1986. The nucleotide sequence of the coding region of tobacco etch virus genomic RNA: Evidence for the synthesis of a single polyprotein. Virology 154:9-20.
3. Atreya, P. L., Atreya, C. D., and Pirone, T. P. 1991. Amino acid substitutions in the coat protein result in loss of insect transmissibility of a plant virus. Proc. Natl. Acad. Sci. USA 88:7887-7891.

4. Chirgwin, J., Przybyla, A., MacDonald, R., and Rutter, W. 1979. Isolation of biologically active ribonucleic acid from sources enriched in ribonuclease. Biochemistry 18:5294-5299.

5. Colinet, D., and Kummert, J. Identification of a sweetpotato feathery mottle virus isolate from China (SPFMV-CH) by the polymerase chain reaction with degenerate primers. J. Virol. Methods. In press.

6. Domier, L. L., Franklin, K. M., Shahabuddin, M., Hellmann, G. M., Overmeyer, J. M., Hiremath, S. T., Siaw, M. F. E., Lomonossoff, G. P., Shaw, J. G., and Rhoads, R. E. 1986. The nucleotide sequence of tobacco vein mottling virus RNA. Nucleic Acids Res. 14:54175430 .

7. Domier, L. L., Shaw, J. G., and Rhoads, R. E. 1987. Potyviral proteins share amino acid sequence homology with picorna-, como-, and caulimoviral proteins. Virology 158:20-27.

8. Hammond, J., Jordan, R. L., Larsen, R. C., and Moyer, J. W. 1992. Use of polyclonal antisera and monoclonal antibodies to examine serological relationships among three filamentous viruses of sweetpotato. Phytopathology 82:713-717.

9. Koonin, E. V. 1991. The phylogeny of RNA-dependent RNA polymerases of positive-strand RNA viruses. J. Gen. Virol. 72:2197-2206.

10. Lain, S., Riechmann, J. L., and Garcia, J. A. 1989. The complete nucleotide sequence of plum pox potyvirus RNA. Virus Res. 13:157172.

11. Langeveld, S. A., Dore, J. M., Memelink, J., Derks, A. F. L. M., Van Der Vlugt, C. I. M., Asjes, C. J., and Bol, J. F. 1991. Identification of potyviruses using the polymerase chain reaction with degenerate primers. J. Gen. Virol. 72:1531-1541.

12. Moyer, J. W., and Salazar, L. F. 1989. Virus and viruslike diseases of sweetpotato. Plant Dis. 73:451-455.

13. Nicolas, O., and Laliberté, J. F. 1991. The use of PCR for cloning of large cDNA fragments of turnip mosaic potyvirus. J. Virol. Methods 32:57-66.

14. Poch, O., Sauvaget, I., Delarue, M., and Tordo, N. 1989. Identification of four conserved motifs among the RNA-dependent polymerase encoding elements. EMBO J. 8:3867-3874.

15. Riechmann, J. L., Lain, S., and Garcia J. A. 1992. Highlights and prospects of potyvirus molecular biology. J. Gen. Virol. 73:1-16.

16. Robaglia, C., Durand-Tardif, M., Tronchet, M., Boudazin, G., AstierManifacier, S., and Casse-Delbart, F. 1989. Nucleotide sequence of potato virus Y (N strain) genomic RNA. J. Gen. Virol. 70:935-947.

17. Robertson, N. L., French, R., and Gray, S. M. 1991. Use of groupspecific primers and the polymerase chain reaction for the detection and identification of luteoviruses. J. Gen. Virol. 72:1473-1477.

18. Rojas, M. R., Gilbertson, R. L., Russell, D. R., and Maxwell, D. $P$. 1993. Use of degenerate primers in the polymerase chain reaction to detect whitefly-transmitted geminiviruses. Plant Dis. 77:340-347.

19. Rybicki, E. P., and Hughes, F. L. 1990. Detection and typing of maize streak virus and other distantly related geminiviruses of grasses by polymerase chain reaction amplification of a conserved viral sequence. J. Gen. Virol. 71:2519-2526.

20. Sambrook, J., Fritsch, E. F., and Maniatis, T. A. 1989. Molecular Cloning: A Laboratory Manual. 2nd ed. Cold Spring Harbor Laboratory, NY.

21. Shukla, D. D., and Ward, C. W. 1989. Identification and classification of potyviruses on the basis of coat protein sequence data and serology. Arch. Virol. 106:171-200.

22. Winter, S., Purac, A., Leggett, F., Frison, E. A., Rossel, H. W., and Hamilton, R. I. 1992. Partial characterization and molecular cloning of a closterovirus from sweetpotato infected with the sweetpotato virus disease complex from Nigeria. Phytopathology 82:869875 . 